Article

\title{
DFT Calculations and Mesophase Study of Coumarin Esters and Its Azoesters
}

\author{
M. Hagar ${ }^{1,2, *} \mathbb{0}$, H.A. Ahmed ${ }^{1,3, *}$ and O.A. Alhaddadd 4 \\ College of Sciences, Chemistry Department, Yanbu, Taibah University, Medina 30799, Saudi Arabia \\ Faculty of Science, Chemistry Department, Alexandria University, Alexandria 21321, Egypt \\ Faculty of Science, Department of Chemistry, Cairo University, Cairo 12613, Egypt \\ College of Sciences, Chemistry Department, Madina Monawara, Taibah University, \\ Medina 30002, Saudi Arabia; OHADDAD@taibahu.edu.sa \\ * Correspondence: mohamedhaggar@gmail.com (M.H.); ahoda@sci.cu.edu.eg (H.A.A.)
}

Received: 16 July 2018; Accepted: 5 September 2018; Published: 8 September 2018

\begin{abstract}
Two groups of coumarin derivatives, 4-methyl-2-oxo-2H-chromen-7-yl 4-alkoxybenzoates (coumarin esters), $\mathbf{I}_{n}$, and 4-methyl-2-oxo-2H-chromen-7-yl 4-(2-(4-alkoxyphenyl)diazenyl) benzoates (coumarin azoesters), $\mathbf{I I}_{n}$, were synthesized and investigated for their mesophase behavior and stability. Each group constitutes five series that differ from each other by length of the mesogenic part. Within each homologous series, the length of the terminal alkoxy group varies between $6,8,10$, 12 and 16 carbons. Mesophase behavior was investigated by differential scanning calorimetry (DSC) and identified by polarized light microscopy (PLM). Density functional theory (DFT) calculations for coumarin derivatives were discussed. The results revealed that the incorporation of azo group incorporated in the mesogenic core decreases the energy differences, increases the dipole moments and stabilities of coumarin azoesters series more than coumarin esters.
\end{abstract}

Keywords: liquid crystal; coumarin derivatives; non-mesomorphic; mesophase stability; DFT calculations

\section{Introduction}

Coumarin derivatives display excellent kinds of photochemical and photophysical properties. They become useful in different applications like brightening agents [1] and organic light-emitting diodes (LED) [2-4]. Moreover, they exhibit an excellent and wide range of biological activity, such as antibiotic, anticancer, antifungal, ant-coagulating, anti-inflammatory, plant growth regulating agents and analytical reagents [5-7]. Additionally, polymeric and non-polymeric coumarin derivatives display liquid-crystalline properties [8-11]. Thus, coumarins have become an interesting molecular framework to be incorporated in numerous electronic organic materials, with potential applications in OLED, solar cells and photo alignment technologies for liquid crystal displays [12,13]. Mesophase stability of an organic compound depends primarily on its molecular architecture in which a slight change in the molecular geometry enables considerable change in its mesomorphic properties [14,15]. Generally, the stability of the mesophase is increased as the polarity and/or polarizability of the central part of the molecule increase. Mesomorphic properties of nematic mesogens are strongly impacted by the lateral group. The degree of such impact is dependent on the size, position, and polarity of the lateral substituent. Sterically, a lateral substituent effectively widens the core and increases the intermolecular separation. This leads to a reduction in lateral interactions [16-18] and, hence, the nematic stability is reduced. Gray [19] has clarified that an increase in the breadth of the molecules reduces the stability of both the nematic and smectic mesophases. High demand for new liquid crystals for applications has led to the preparation and study of numerous mesogens, particularly thermotropic liquid crystals $[14,15]$. 
Most thermotropic liquid crystals are rod-like molecules having a rigid core composed of two or more phenyl rings and one or more flexible terminal alkyl chains. Coumarin derivatives have readily available electrons that enable the photo-excitation of the dye to an excited state. Due to this attractive structure-property relationship, coumarins allow the synthesis of suitable dyes with appropriate groups by either adding chromophore groups or expanding the $\pi$ system (a conjugation path) between them. Connecting theoretical calculations of molecular structure with experimental data is one of our interests [20-23]. In liquid crystals, the molecular structures as well as the interactions between the molecules have large effects on their physical properties [24-27].

The mesomorphic properties of nematic mesogens are strongly influenced by a lateral group appended to a nematic core. The extent of such effect is dependent on the size, position, and polarity of the lateral substituent. A large lateral substituent effectively widens the core and increases the intermolecular separation, and this reduces nematic stability by a reduction of the lateral interactions [16-18]. Furthermore, Gray [19] reported that an increase in the breadth of the molecules reduces the stability of both the nematic and smectic mesophases.

In the present work, in order to obtain a further understanding of the structure-property relationship of liquid crystalline compounds having coumarin derivatives, two series of lateral methyl coumarin esters, $\mathbf{I}_{n}$, and coumarin azoesters $\mathbf{I I}_{n}$, have been synthesizes and investigated in terms of their mesophase behavior as well as DFT calculation to illustrate the effect of the length of the alkoxy chain as well as the mesogenic part on their mesophase stability (Figure 1).

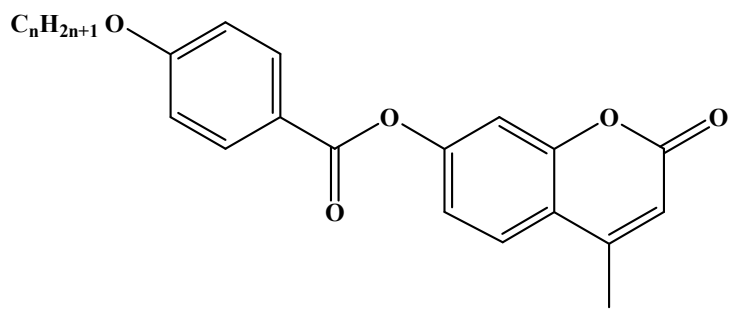

$\mathbf{I}_{n}$

$\mathrm{n}=6,8,10,12$, and 16<smiles>CCCCCOc1ccc(/C=N/c2ccc(C(=O)Oc3ccc4c(C)cc(=O)oc4c3)cc2)cc1</smiles>

$\mathbf{I I} n$

$\mathrm{n}=6,8,10,12$, and 16

Figure 1. Prepared compounds $\mathbf{I}_{n}$ and $\mathbf{I}_{n}$.

\section{Experimental}

\subsection{Materials}

Hexyl bromide, octyl bromide, decyl bromide, dodecyl bromide and hexadecyl bromide were obtained from Sigma Aldrich (Darmstadt, Germany). Phenol, $p$-aminobezoic acid, 4-n-hexyoxyl 
benzoic acid, 4-n-octoyloxy benzoic acid, 4-n-decyloxy benzoic acid and 4-n-dodecyloxy benzoic acid were obtained from Merck (Darmstadt, Germany). N,N'-dicyclohexylcarbodiimide (DCC), tributylamoniumbromide (TBAB) and 4-dimethylaminopyridine (DMAP) were purchased from Aldrich (Missouri, WI, USA). Dichloromethane, ethanol and methanol were of pure grade and purchased Aldrich (Missouri, WI, USA).

\subsection{Synthesis of Coumain Derivatives}

Coumarin esters, $\mathbf{I}_{n}$ and coumarin azoesters $\mathbf{I I}_{n}$, were synthesizes according to the following Scheme 1:

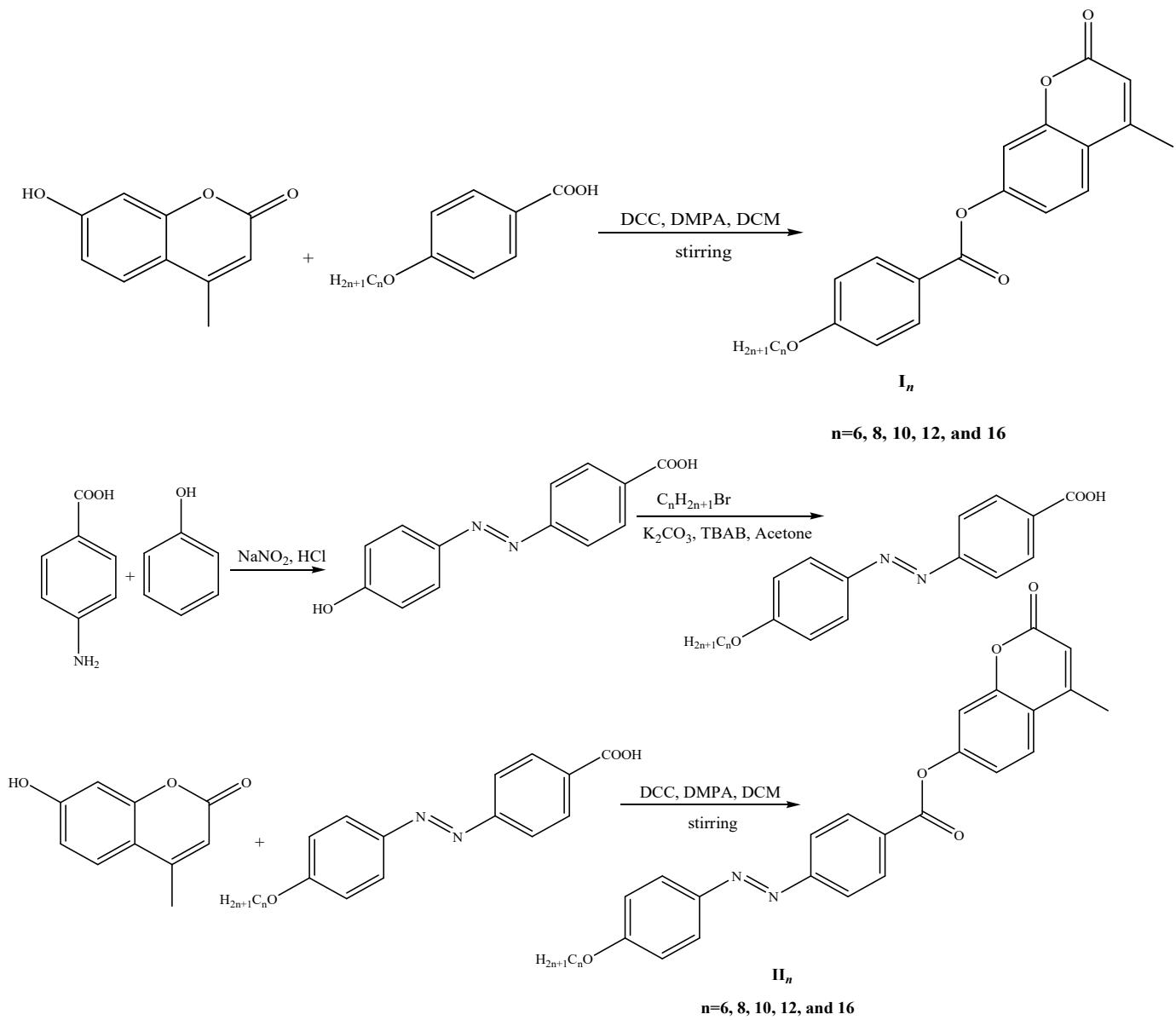

Scheme 1. Synthesis of coumarin derivatives $\mathbf{I}_{n}$ and $\mathbf{I I}_{n}$.

\subsubsection{Synthesis of 4-methyl-2-oxo-2H-chromen-7-yl 4-alkoxybenzoate, In}

To a mixture of the 7-hydroxy-4-methyl-2H-chromen-2-one (0.01 mole) and 0.01 mole of 4-alkoxybenzoic acid in $25 \mathrm{~mL}$ dry methylene chloride $N, N^{\prime}$-dicyclohexylcarbodiimide (DCC, 0.02 mole) and few crystals of 4-dimethylaminopyridine (DMAP) were added. The reaction mixture was stirred for $72 \mathrm{~h}$ at room temperature. The separated precipitate was filtered off and the filtrate was evaporated. The solid residue obtained was recrystallized from ethanol.

4-methyl-2-oxo-2H-chromen-7-yl 4-hexyloxybenzoate $\mathbf{I}_{6}$.

Yield: $89.2 \%$; mp. $110.0^{\circ} \mathrm{C}$, FTIR $\left(\dot{v}, \mathrm{~cm}^{-1}\right)$ : 2923, $2856\left(\mathrm{CH}_{2}\right.$ stretching), $1722(\mathrm{C}=\mathrm{O}), 1625(\mathrm{C}=\mathrm{N})$, $1605(\mathrm{C}=\mathrm{C}), 1469\left(\mathrm{C}-\mathrm{O}_{\text {Asym }}\right), 1245\left(\mathrm{C}-\mathrm{O}_{\text {Sym }}\right)$. Elemental analyses: $\mathrm{C}_{23} \mathrm{H}_{24} \mathrm{O}_{5}$ Found (Calc.): $\mathrm{C}, 72.21$ (72.61); H, 6.29 (6.36). 
4-methyl-2-oxo-2H-chromen-7-yl 4-octyloxybenzoate $\mathbf{I}_{\mathbf{8}}$.

Yield: 91.3\%; mp. $104.0^{\circ} \mathrm{C}$, FTIR (v́, $\left.\mathrm{cm}^{-1}\right)$ : 2919, $2846\left(\mathrm{CH}_{2}\right.$ stretching), $1724(\mathrm{C}=\mathrm{O}), 1624(\mathrm{C}=\mathrm{N})$, $1604(\mathrm{C}=\mathrm{C}), 1467\left(\mathrm{C}-\mathrm{O}_{\text {Asym }}\right), 1253\left(\mathrm{C}-\mathrm{O}_{\text {Sym }}\right)$. Elemental analyses: $\mathrm{C}_{25} \mathrm{H}_{28} \mathrm{O}_{5}$ Found (Calc.): $\mathrm{C}, 73.39$ (73.51); $\mathrm{H}, 6.88$ (6.91).

4-methyl-2-oxo-2H-chromen-7-yl 4-decyloxybenzoate $\mathbf{I}_{10}$

Yield: $93.8 \%$; mp. $108.0^{\circ} \mathrm{C}$, FTIR (v́, $\left.\mathrm{cm}^{-1}\right)$ : 2921, $2851\left(\mathrm{CH}_{2}\right.$ stretching), $1726(\mathrm{C}=\mathrm{O}), 1626(\mathrm{C}=\mathrm{N})$, $1604(\mathrm{C}=\mathrm{C}), 1469\left(\mathrm{C}-\mathrm{O}_{\text {Asym }}\right), 1247\left(\mathrm{C}-\mathrm{O}_{\text {Sym }}\right)$. Elemental analyses: Found (Calc.): $\mathrm{C}_{27} \mathrm{H}_{32} \mathrm{O}_{5} \mathrm{C}, 74.33$ (74.29); $\mathrm{H}, 7.45$ (7.39).

4-methyl-2-oxo-2H-chromen-7-yl 4-dodecyloxybenzoate $\mathbf{I}_{12}$

Yield: $90.7 \%$; $\mathrm{mp} 107.0^{\circ} \mathrm{C}$, FTIR $\left(\hat{v}, \mathrm{~cm}^{-1}\right): 2921,2850\left(\mathrm{CH}_{2}\right.$ stretching $), 1726(\mathrm{C}=\mathrm{O}), 1625(\mathrm{C}=\mathrm{N})$, $1604(\mathrm{C}=\mathrm{C}), 1469\left(\mathrm{C}-\mathrm{O}_{\text {Asym }}\right), 1247\left(\mathrm{C}-\mathrm{O}_{\text {Sym }}\right)$. Elemental analyses: Found (Calc.): $\mathrm{C}_{29} \mathrm{H}_{36} \mathrm{O}_{5} \mathrm{C}, 74.75$ (74.97); $\mathrm{H}, 7.64$ (7.81).

4-methyl-2-oxo-2H-chromen-7-yl 4-hexadecyloxybenzoate $\mathbf{I}_{16}$

Yield: $90.9 \%$; mp. $109.0^{\circ} \mathrm{C}$, FTIR $\left(\dot{v}, \mathrm{~cm}^{-1}\right): 2919,2850\left(\mathrm{CH}_{2}\right.$ stretching $), 1726(\mathrm{C}=\mathrm{O}), 1626(\mathrm{C}=\mathrm{N})$, $1604(\mathrm{C}=\mathrm{C}), 1470\left(\mathrm{C}-\mathrm{O}_{\text {Asym }}\right), 1247\left(\mathrm{C}-\mathrm{O}_{\text {Sym }}\right)$. Elemental analyses: $\mathrm{C}_{33} \mathrm{H}_{44} \mathrm{O}_{5}$ Found (Calc.): $\mathrm{C}, 76.01$ (76.12); $\mathrm{H}, 8.33$ (8.52).

\subsubsection{Synthesis of 4-(2-(4-alkoxyphenyl)diazenyl)benzoic acid}

A mixture of 4-(2-(4-hydroxyphenyl)diazenyl)benzoic acid (5.0 mmol), alkylbromide $(6.0 \mathrm{mmol})$, tetrabutylammonium bromide $(0.17 \mathrm{~g}, 0.50 \mathrm{mmol})$, and the mixture of potassium carbonate $(0.28 \mathrm{~g}$, $2.0 \mathrm{mmol})$ and potassium hydroxide $(0.11 \mathrm{~g}, 2.0 \mathrm{mmol})$ was heated under reflux for $6 \mathrm{~h}$. After cooling, the reaction mixture was neutralized with $4 \mathrm{~N} \mathrm{HCl}$ and extracted with methylene chloride $(3 \times 20 \mathrm{~mL})$. The organic layer was dried over anhydrous $\mathrm{MgSO}_{4}$, filtered, and the solvent was evaporated to dryness. The products were purified by recrystalization by aqueous ethanol (1:1).

\subsubsection{Synthesis of 4-methyl-2-oxo-2H-chromen-7-yl 4-(2-(4-alkoxyphenyl)diazenyl)benzoate, $\mathbf{I I}_{n}$}

$N, N^{\prime}$-dicyclohexylcarbodiimide (DCC, 0.02 mole) and few crystals of 4-dimethylaminopyridine (DMAP) were added to a mixture of the 7-hydroxy-4-methyl-2H-chromen-2-one (0.01 mole) and 0.01 mole of 4-(2-(4-alkoxyphenyl)diazenyl)benzoic acid in $25 \mathrm{~mL}$ dry methylene chloride. The reaction mixture was stirred for $72 \mathrm{~h}$ at room temperature. The separated dicyclohexylurea (DCU) was filtered off and the filtrate was evaporated. The solid residue obtained was recrystallized from ethanol.

4-methyl-2-oxo-2H-chromen-7-yl 4-(2-(4-hexyloxyphenyl)diazenyl)benzoate $\mathbf{I I}_{6}$

Yield: $92.3 \%$; mp $122.7^{\circ} \mathrm{C}$, FTIR $\left(\hat{v}, \mathrm{~cm}^{-1}\right)$ : 2928, $2856\left(\mathrm{CH}_{2}\right.$ stretching), $1726(\mathrm{C}=\mathrm{O}), 1602(\mathrm{C}=\mathrm{C})$, $1498\left(\mathrm{C}-\mathrm{O}_{\text {Asym }}\right), 1245\left(\mathrm{C}-\mathrm{O}_{\text {Sym }}\right) .{ }^{1} \mathrm{H}$ NMR $\left(400 \mathrm{MHz}, \mathrm{CDCl}_{3}\right): \delta / \mathrm{ppm}: 0.92\left(\mathrm{t}, 3 \mathrm{H}, \mathrm{CH}_{3}\left(\mathrm{CH}_{2}\right)_{3} \mathrm{CH}_{2} \mathrm{CH}_{2} \mathrm{O}\right.$, $J=6.6 \mathrm{~Hz}), 1.15-1.36\left(\mathrm{~m}, 6 \mathrm{H}, \mathrm{CH}_{3}\left(\mathrm{CH}_{2}\right)_{3} \mathrm{CH}_{2} \mathrm{CH}_{2} \mathrm{O}\right), 1.76-1.85\left(\mathrm{~m}, 2 \mathrm{H}, \mathrm{CH}_{3}\left(\mathrm{CH}_{2}\right)_{3} \mathrm{CH}_{2} \mathrm{CH}_{2} \mathrm{O}\right), 2.47$ $\left(\mathrm{s}, 3 \mathrm{H}, \mathrm{CH}_{3}\right), 4.07\left(\mathrm{t}, 2 \mathrm{H}, \mathrm{CH}_{3}\left(\mathrm{CH}_{2}\right)_{3} \mathrm{CH}_{2} \mathrm{CH}_{2} \mathrm{O}, J=6.4 \mathrm{~Hz}\right), 6.31(\mathrm{~s}, 1 \mathrm{H}, \mathrm{Ar}-\mathrm{H}) 7.00-7.04(\mathrm{~m}, 2 \mathrm{H}, \mathrm{Ar}-\mathrm{H})$, 7.24-7.29 (m, 2H, Ar-H), 7.66-7.69 (m, 2H, Ar-H), 7.89-8.00 (m, 3H, Ar-H), 8.33 (d, 2H, J = 8.7 Hz, $\mathrm{Ar}-\mathrm{H}) .{ }^{13} \mathrm{C}$ NMR $\left(101 \mathrm{MHz}, \mathrm{CDCl}_{3}\right) \delta=164.04,162.50,160.43,155.99,154.17,153.36,152.02,146.85$, 131.40, 129.60, 127.61, 125.49, 125.13, 122.65, 118.27, 117.97, 114.87, 110.69, 68.50, 32.36, 29.14, 25.70, 22.61, 18.80, 14.05. Elemental analyses: $\mathrm{C}_{29} \mathrm{H}_{28} \mathrm{~N}_{2} \mathrm{O}_{5}$ Found (Calc.): C, 72.15 (71.88); H, 5.99 (5.82); N, 5.49 (5.78).

4-methyl-2-oxo-2H-chromen-7-yl 4-(2-(4-octyloxyphenyl)diazenyl)benzoate II $_{8}$

Yield: $91.7 \%$; mp $107.5^{\circ} \mathrm{C}$, FTIR $\left(v, \mathrm{~cm}^{-1}\right): 2925,2855\left(\mathrm{CH}_{2}\right.$ stretching), $1726(\mathrm{C}=\mathrm{O}), 1603(\mathrm{C}=\mathrm{C})$, $1499\left(\mathrm{C}-\mathrm{O}_{\text {Asym }}\right), 1246\left(\mathrm{C}-\mathrm{O}_{\text {Sym }}\right) .{ }^{1} \mathrm{H}$ NMR $\left(400 \mathrm{MHz}, \mathrm{CDCl}_{3}\right): \delta / \mathrm{ppm}: 0.91\left(\mathrm{t}, 3 \mathrm{H}, \mathrm{CH}_{3}\left(\mathrm{CH}_{2}\right)_{5} \mathrm{CH}_{2} \mathrm{CH}_{2} \mathrm{O}\right.$, $J=6.6 \mathrm{~Hz}), 1.12-1.39\left(\mathrm{~m}, 10 \mathrm{H}, \mathrm{CH}_{3}\left(\mathrm{CH}_{2}\right)_{5} \mathrm{CH}_{2} \mathrm{CH}_{2} \mathrm{O}\right), 1.69-1.82\left(\mathrm{~m}, 2 \mathrm{H}, \mathrm{CH}_{3}\left(\mathrm{CH}_{2}\right)_{5} \mathrm{CH}_{2} \mathrm{CH}_{2} \mathrm{O}\right), 2.45$ 
$\left(\mathrm{s}, 3 \mathrm{H}, \mathrm{CH}_{3}\right), 4.05\left(\mathrm{t}, 2 \mathrm{H}, \mathrm{CH}_{3}\left(\mathrm{CH}_{2}\right)_{5} \mathrm{CH}_{2} \mathrm{CH}_{2} \mathrm{O}, J=6.5 \mathrm{~Hz}\right), 6.31(\mathrm{~s}, 1 \mathrm{H}, \mathrm{Ar}-\mathrm{H}) 7.00-7.04(\mathrm{~m}, 2 \mathrm{H}, \mathrm{Ar}-\mathrm{H})$, 7.21-7.31 (m, 2H, Ar-H), 7.62-7.67 (m, 2H, Ar-H), 7.92-8.02 (m, 3H, Ar-H), $8.33(\mathrm{~d}, 2 \mathrm{H}, J=8.8 \mathrm{~Hz}$, Ar-H). Elemental analyses: $\mathrm{C}_{31} \mathrm{H}_{32} \mathrm{~N}_{2} \mathrm{O}_{5}$ Found (Calc.): $\mathrm{C}, 72.45$ (72.64); H, 6.01 (6.29); N, 5.12 (5.47).

4-methyl-2-oxo-2H-chromen-7-yl 4-(2-(4-decyloxyphenyl)diazenyl)benzoate $\mathbf{I I}_{10}$

Yield: 88.9\%; mp $137.5{ }^{\circ} \mathrm{C}$, FTIR $\left(\dot{v}, \mathrm{~cm}^{-1}\right): 2926,2853\left(\mathrm{CH}_{2}\right.$ stretching), $1724(\mathrm{C}=\mathrm{O}), 1605$ $(\mathrm{C}=\mathrm{C}), 1497\left(\mathrm{C}-\mathrm{O}_{\text {Asym }}\right), 1248\left(\mathrm{C}-\mathrm{O}_{\text {Sym }}\right) .{ }^{1} \mathrm{H}$ NMR $\left(400 \mathrm{MHz}, \mathrm{CDCl}_{3}\right): \delta / \mathrm{ppm}: 0.89(\mathrm{t}, 3 \mathrm{H}$, $\left.\mathrm{CH}_{3}\left(\mathrm{CH}_{2}\right)_{7} \mathrm{CH}_{2} \mathrm{CH}_{2} \mathrm{O}, J=6.9 \mathrm{~Hz}\right), 1.08-1.41\left(\mathrm{~m}, 14 \mathrm{H}, \mathrm{CH}_{3}\left(\mathrm{CH}_{2}\right)_{7} \mathrm{CH}_{2} \mathrm{CH}_{2} \mathrm{O}\right), 1.79-1.88(\mathrm{~m}, 2 \mathrm{H}$, $\left.\mathrm{CH}_{3}\left(\mathrm{CH}_{2}\right)_{7} \mathrm{CH}_{2} \mathrm{CH}_{2} \mathrm{O}\right), 2.44\left(\mathrm{~s}, 3 \mathrm{H}, \mathrm{CH}_{3}\right), 4.09\left(\mathrm{t}, 2 \mathrm{H}, \mathrm{CH}_{3}\left(\mathrm{CH}_{2}\right)_{7} \mathrm{CH}_{2} \mathrm{CH}_{2} \mathrm{O}, J=6.5 \mathrm{~Hz}\right), 6.31$ (s, 1H, Ar-H) 7.00-7.04 (m, 2H, Ar-H), 7.23-7.30 (m, 2H, Ar-H), 7.60-7.68 (m, 2H, Ar-H), 7.91-8.02 $(\mathrm{m}, 3 \mathrm{H}, \mathrm{Ar}-\mathrm{H}), 8.34(\mathrm{~d}, 2 \mathrm{H}, J=8.8 \mathrm{~Hz}, \mathrm{Ar}-\mathrm{H})$. Elemental analyses: $\mathrm{C}_{33} \mathrm{H}_{36} \mathrm{~N}_{2} \mathrm{O}_{5}$ Found (Calc.): $\mathrm{C}, 73.03$ (73.31); H, 6.35 (6.71); N, 4.75 (5.18).

4-methyl-2-oxo-2H-chromen-7-yl 4-(2-(4-dodecyloxyphenyl)diazenyl)benzoate $\mathbf{I I}_{12}$

Yield: 92.2\%; mp $131.0{ }^{\circ} \mathrm{C}$, FTIR $\left(\dot{v}, \mathrm{~cm}^{-1}\right): 2918,2851\left(\mathrm{CH}_{2}\right.$ stretching), $1727(\mathrm{C}=\mathrm{O}), 1603$

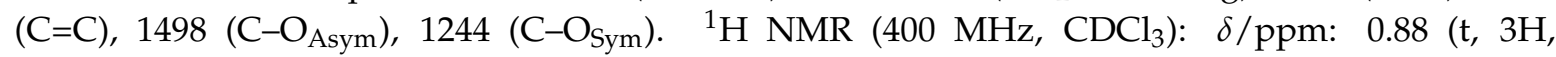
$\left.\mathrm{CH}_{3}\left(\mathrm{CH}_{2}\right)_{9} \mathrm{CH}_{2} \mathrm{CH}_{2} \mathrm{O}, J=6.5 \mathrm{~Hz}\right), 1.21-1.57\left(\mathrm{~m}, 6 \mathrm{H}, \mathrm{CH}_{3}\left(\mathrm{CH}_{2}\right)_{9} \mathrm{CH}_{2} \mathrm{CH}_{2} \mathrm{O}\right), 1.80-1.87(\mathrm{~m}, 2 \mathrm{H}$, $\left.\mathrm{CH}_{3}\left(\mathrm{CH}_{2}\right)_{9} \mathrm{CH}_{2} \mathrm{CH}_{2} \mathrm{O}\right), 2.47\left(\mathrm{~s}, 3 \mathrm{H}, \mathrm{CH}_{3}\right), 4.08\left(\mathrm{t}, 2 \mathrm{H}, \mathrm{CH}_{3}\left(\mathrm{CH}_{2}\right)_{9} \mathrm{CH}_{2} \mathrm{CH}_{2} \mathrm{O}, J=6.4 \mathrm{~Hz}\right), 6.31$ $(\mathrm{s}, 1 \mathrm{H}, \mathrm{Ar}-\mathrm{H}) 7.04(\mathrm{~d}, 2 \mathrm{H}, J=8.4 \mathrm{~Hz}, \mathrm{Ar}-\mathrm{H}), 7.24-7.29(\mathrm{~m}, 2 \mathrm{H}, \mathrm{Ar}-\mathrm{H}), 7.70(\mathrm{~d}, 2 \mathrm{H}, J=8.4 \mathrm{~Hz}, \mathrm{Ar}-\mathrm{H})$, 7.89-8.00 (m, 3H, Ar-H), 8.35 (d, 2H, J = 8.7 Hz, Ar-H). ${ }^{13} \mathrm{C}$ NMR $\left(101 \mathrm{MHz}, \mathrm{CDCl}_{3}\right) \delta=164.15$, $162.61,160.54,156.09,154.30,153.36,151.94,146.86,131.40,129.59,125.49,125.39,122.64,118.26,118.02$, $114.87,114.65,110.69,68.50,31.93,29.68,29.65,29.61,29.58,29.39,29.37,29.17,26.02,22.71,18.80,14.14$. Elemental analyses: $\mathrm{C}_{35} \mathrm{H}_{40} \mathrm{~N}_{2} \mathrm{O}_{5}$ Found (Calc.): C, 73.79 (73.92); $\mathrm{H}, 6.61$ (7.09); N, 4.49 (4.93).

4-methyl-2-oxo-2H-chromen-7-yl 4-(2-(4-hexadecyloxyphenyl)diazenyl)benzoate $\mathbf{I I}_{16}$

Yield: 90.1\%; mp $126.0-\mathrm{C}$, FTIR $\left(\dot{v}, \mathrm{~cm}^{-1}\right): 2918,2849\left(\mathrm{CH}_{2}\right.$ stretching), $1726(\mathrm{C}=\mathrm{O}), 1602$ $(\mathrm{C}=\mathrm{C}), 1501\left(\mathrm{C}-\mathrm{O}_{\text {Asym }}\right), 1246\left(\mathrm{C}-\mathrm{O}_{\text {Sym }}\right) .{ }^{1} \mathrm{H}$ NMR $\left(400 \mathrm{MHz}, \mathrm{CDCl}_{3}\right): \delta / \mathrm{ppm}: 0.91(\mathrm{t}, 3 \mathrm{H}$, $\left.\mathrm{CH}_{3}\left(\mathrm{CH}_{2}\right)_{13} \mathrm{CH}_{2} \mathrm{CH}_{2} \mathrm{O}, J=6.5 \mathrm{~Hz}\right), 1.21-1.83\left(\mathrm{~m}, 6 \mathrm{H}, \mathrm{CH}_{3}\left(\mathrm{CH}_{2}\right){ }_{13} \mathrm{CH}_{2} \mathrm{CH}_{2} \mathrm{O}\right), 2.46\left(\mathrm{~s}, 3 \mathrm{H}, \mathrm{CH}_{3}\right)$, $4.06\left(\mathrm{t}, 2 \mathrm{H}, \mathrm{CH}_{3}\left(\mathrm{CH}_{2}\right)_{13} \mathrm{CH}_{2} \mathrm{CH}_{2} \mathrm{O}, J=6.8 \mathrm{~Hz}\right), 6.31(\mathrm{~s}, 1 \mathrm{H}, \mathrm{Ar}-\mathrm{H}) 7.04(\mathrm{~d}, 2 \mathrm{H}, J=8.4 \mathrm{~Hz}, \mathrm{Ar}-\mathrm{H})$, 7.24-7.29 (m, 2H, Ar-H), $7.70(\mathrm{~d}, 2 \mathrm{H}, J=8.4 \mathrm{~Hz}, \mathrm{Ar}-\mathrm{H}), 7.89-8.00(\mathrm{~m}, 3 \mathrm{H}, \mathrm{Ar}-\mathrm{H}), 8.35(\mathrm{~d}, 2 \mathrm{H}, J=8.8 \mathrm{~Hz}$, $\mathrm{Ar}-\mathrm{H}$ ). Elemental analyses: $\mathrm{C}_{39} \mathrm{H}_{48} \mathrm{~N}_{2} \mathrm{O}_{5}$ Found (Calc.): C, 74.68 (74.97); H, 7.63 (7.74); N, 4.39 (4.48).

\subsection{Characterization}

The purity of the prepared samples was checked with thin-layer chromatography (TLC) using TLC sheets coated with silica gel (E Merck), and $\mathrm{CH}_{2} \mathrm{Cl}_{2} / \mathrm{CH}_{3} \mathrm{OH}$ (9:1) as eluent, whereby only one spot was detected by a UV-lamp.

Infrared spectra were recorded using Perkin-Elmer B25 spectrophotometer (Perkin-Elmer, Inc., Shelton, CT USA). ${ }^{1} \mathrm{H}$ NMR spectra were performed using a Varian EM $350 \mathrm{~L} 300 \mathrm{MHz}$ spectrometer (Varian, Oxford, UK) using tetramethylsilane as internal standard and $\mathrm{CDCl}_{3}$ as solvent; the chemical shift values recorded as $\delta$ (ppm units). Elemental analyses for final products were carried out on Thermo Scientific Flash 2000 CHS/O Elemental Analyzer, Milan, Italy.

Calorimetric measurements were carried out using a TA Instruments Co. Q20 Differential Scanning Calorimeter (TA Instruments Co. Q20, DSC, New Castle, DE USA). The DSC was calibrated using the melting temperature and enthalpy of indium and lead. DSC investigation was carried out for small samples (2-3 mg) placed in aluminum pans. All measurements were achieved at a heating rate of $10^{\circ} \mathrm{C} / \mathrm{min}$ in inert atmosphere of nitrogen gas $(30 \mathrm{~mL} / \mathrm{min})$ and all transition recorded from the second heating scan.

Transition temperatures were checked and types of mesophases identified, for all compounds prepared, with a standard polarized light microscope (PLM, Wild, Germany) attached with Mettler FP82HT hot stage. 


\subsection{Methods and Calculations}

All calculations for the studied coumarin derivatives were carried out using Gaussian 09 software (version 09) [28] on a Pentium IV processor personal computer. The calculations were performed by DFT/B3LYP methods using 6-31G (d,p) basis set. The geometries were optimized by minimizing the energies with respect to all geometrical parameters without imposing any molecular symmetry constraints. Gauss View [29] has been used to draw the structures of the optimized geometries. Also, frequency calculations were performed using the same level of theory. The frequency calculations showed that all structures were stationary points in the geometry optimization procedures and none showed imaginary frequencies in the vibrational analyses. Vibrational mode assignments were made by visual inspection of the modes animated by using Gauss View program.

\section{Results and Discussion}

\subsection{Infrared Absorption Spectra of Components $\left(\mathbf{I}_{n}\right)$}

Infrared spectra observed for the all compounds $\mathbf{I}_{n}$ and $\mathbf{I I}_{n}$ under investigation showed no significant effect of the length of the alkoxy chain on the position of FTIR absorption bands of the main characteristic functional groups.

\subsection{Mesophase Behavior of the Investigated Coumarin Derivatives}

Transition temperatures and transition enthalpies as measured by DSC, and the phases identified by polarized light microscopy PLM, for synthesized derivatives coumarinesters, $\mathbf{I}_{n}$, and coumarinazoesters, $\mathbf{I I}_{n}$, are summarized in Table 1 . DSC curves for $\mathbf{I}_{8}$ and $\mathbf{I I}_{\mathbf{1 0}}$ upon heating and cooling are depicted in Figure 2 as representative examples. The effect of increasing alkoxy-chain length on the mesophase behavior of compounds in series $\mathbf{I}_{\boldsymbol{n}}$ is represented graphically in Figure 3 a and those of coumarinazoesters $\mathbf{I I}_{n}$, for comparison, are depicted in Figure $3 \mathbf{b}$.

The data in Table 1 and Figure 3 reveal that all coumarinesters, $\mathbf{I}_{n}$, series are non-mesomorphic. Conversely, all compounds in Coumarin azoesters group $\mathbf{I I}_{\boldsymbol{n}}$ are enantiotrpically mesomorphic, these results are consistent with previous finding [30]. All members of group $\mathbf{I I}_{\boldsymbol{n}}$ are dimorphic exhibit smectic C (SmC) and nematic phases $(\mathrm{N})$ except $\mathbf{I I}_{16}$ is monomorphic showing only SmC phase. Phases were confirmed by the miscibility method, using 4-hexadodecyloxybenzoic acid as the mesophase reference. Generally, the stability of the mesophase is augmented by an increase in the polarity and/or polarizability of the mesogenic part of the molecule. It was found that [19], the stability and types of the mesophase produced are dependent on the dipole moment of the mesogenic portion of the molecule. The results clearly show a dependence on the polarizability of the mesogenic core, and that coumarinazoesters $\left(\mathbf{I I}_{n}\right)$ homologues are mesomorphic with high stability.

Table 1. Phase transition temperatures $\left({ }^{\circ} \mathrm{C}\right)$, enthalpy of transition $\Delta H, \mathrm{~kJ} /$ mole, normalized entropy $\Delta S$, and $\sqrt{ } T_{\mathbf{C}}, \mathrm{K}^{1 / 2}$ for compounds $\mathbf{I}_{n}$ and $\mathbf{I I}_{n}$.

\begin{tabular}{|c|c|c|c|c|c|c|c|c|c|c|c|}
\hline Comp. & $T_{\mathrm{Cr}-\mathrm{SmC}}$ & $\Delta H_{\mathrm{Cr}-\mathrm{SmC}}$ & $T_{\mathrm{SmC-N}}$ & $\Delta H_{\mathrm{SmC}-\mathrm{N}}$ & $\Delta S_{\mathrm{SmC-N}} / \mathrm{R}$ & $T_{\text {SmC-I }}$ & $\Delta H_{\text {SmC-I }}$ & $T_{\mathrm{N}-\mathrm{I}}$ & $\Delta H_{\mathrm{N}-\mathrm{I}}$ & $\Delta S_{\mathrm{N}-\mathrm{I}} / \mathrm{R}$ & $\sqrt{ } T_{\mathrm{C}}$ \\
\hline $\mathrm{I}_{6}$ & 110.3 & 31.72 & - & - & - & - & - & - & - & - & - \\
\hline $\mathbf{I}_{8}$ & 103.9 & 28.59 & - & - & - & - & - & - & - & - & - \\
\hline $\mathbf{I}_{10}$ & 108.7 & 33.29 & - & - & - & - & - & - & - & - & - \\
\hline $\mathbf{I}_{12}$ & 107.7 & 29.10 & - & - & - & - & - & - & - & - & - \\
\hline $\mathbf{I}_{16}$ & 109.0 & 30.96 & - & - & - & - & - & - & - & - & - \\
\hline $\mathrm{II}_{6}$ & 122.7 & 25.56 & 163.3 & 1.81 & 0.50 & & & 220.7 & 0.92 & 0.22 & 22.22 \\
\hline $\mathrm{II}_{8}$ & 107.5 & 24.29 & 163.5 & 1.63 & 0.45 & & & 188.4 & 0.55 & 0.14 & 21.49 \\
\hline $\mathrm{II}_{10}$ & 137.5 & 28.74 & 174.2 & 1.72 & 0.46 & & & 187.9 & 0.56 & 0.15 & 21.47 \\
\hline $\mathrm{II}_{12}$ & 130.9 & 31.73 & 177.0 & 2.74 & 0.73 & & & 182.0 & 0.63 & 0.17 & 21.33 \\
\hline $\mathrm{II}_{16}$ & 125.9 & 26.77 & - & - & & 174.0 & 2.43 & - & - & - & 21.15 \\
\hline
\end{tabular}

Abbreviations: $T_{\mathrm{Cr}-\mathrm{SmC}}=$ crystal to smectic $\mathrm{C}$ phase transition; $T_{\mathrm{SmC}-\mathrm{N}}=$ smectic $\mathrm{C}$ to Nematic transition; $T_{\mathrm{SmC-I}}=$ smectic $\mathrm{C}$ to isotropic liquid transition; $\boldsymbol{T}_{\mathrm{N}-\mathrm{I}}=$ Nematic to isotropic liquid transition. $\Delta \boldsymbol{H}_{\mathrm{Cr}-\mathrm{SmC}}=$ crystal to smectic $\mathrm{C}$ phase transition; $\Delta \boldsymbol{H}_{\mathrm{SmC}-\mathrm{N}}=$ smectic $\mathrm{C}$ to Nematic transition; $\Delta \boldsymbol{H}_{\mathrm{N}-\mathrm{I}}=$ Nematic to isotropic liquid transition; $\Delta S_{\mathrm{SmC}-\mathrm{N}} / \mathrm{R}=$ smectic $\mathrm{C}$ to Nematic transition entropy; $\Delta S_{\mathrm{N}-\mathrm{I}} / \mathrm{R}=$ Nematic to isotropic liquid transition entropy. 

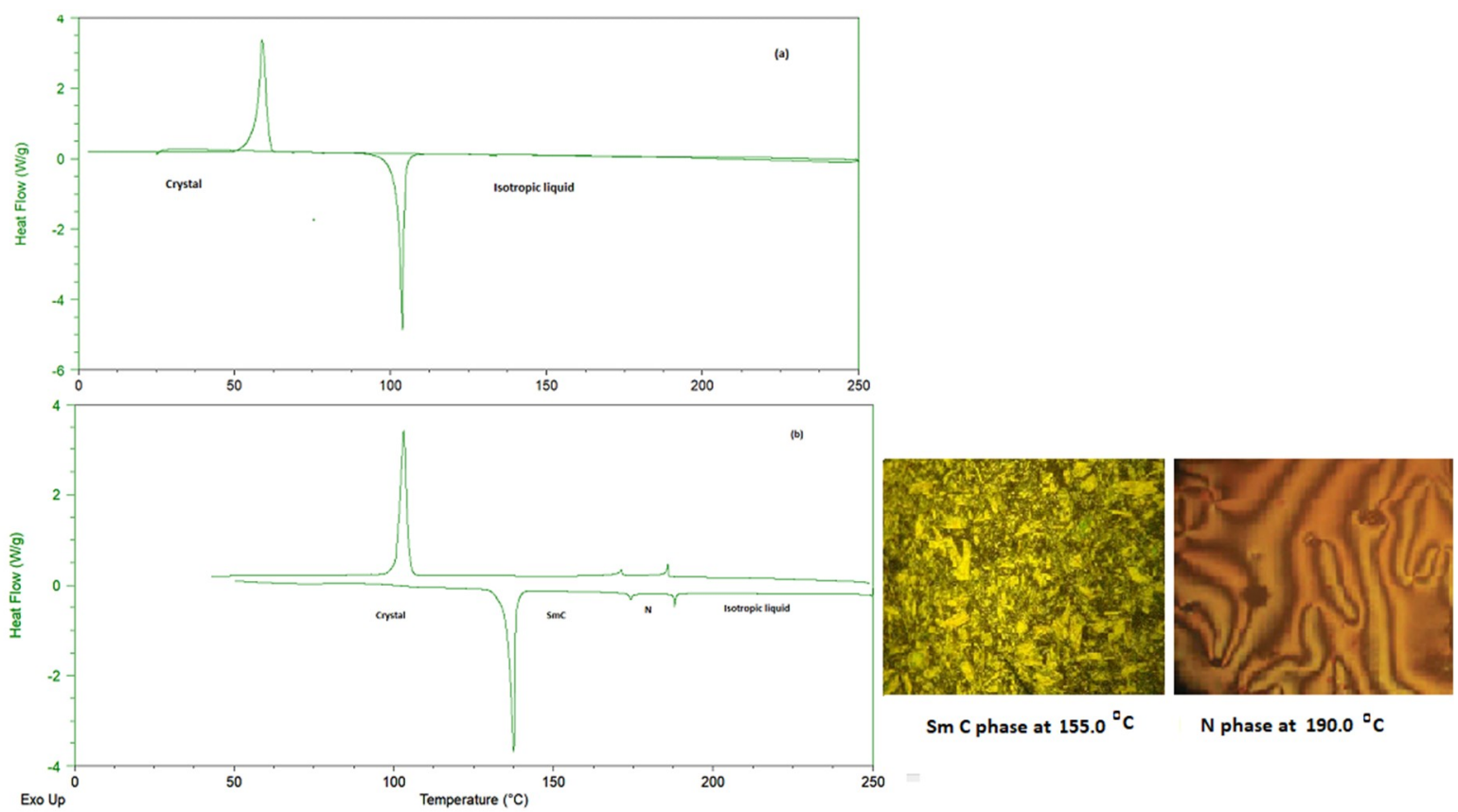

Figure 2. DSC thermograms of some representative compounds recorded from heating and cooling at a rate of $10^{\circ} \mathrm{C} / \mathrm{min}$ for: (a) $\mathbf{I}_{8}$ and (b) $\mathbf{I I}_{10}$.

Figure $3 \mathrm{~b}$ shows that the nematic-to-isotropic transition temperatures $\left(\boldsymbol{T}_{\mathrm{N}-\mathrm{I}}\right)$ decrease gradually with the increase of the alkoxy-chain length $(n)$. This trend is in accordance with that shown by Gray [19] and Imrie and Taylor [31] in which the nematic-to-isotropic transition temperatures fall with increasing alkoxy-chain length, and also for the smectic phase, the smectic-nematic, or smectic-to-isotropic transition temperatures rise gradually as the alkoxy chain lengthens.

The mesophase behavior of a calamitic mesogen is affected by the molecular-molecular interactions that depend mainly on geometry of the molecules, polarizability anisotropy of the core molecule, as well as the stereo electronic properties of the whole molecule. Therefore, in the present studied coumarin derivatives, molecular association of the rod-like molecules, and consequently their mesophases stability $\left(T_{\mathrm{c}}\right)$ depends mainly on lateral adhesion of linear molecules that increases with the increase of the alkoxy-chain length (n). However, the increased alkyl-chain length reduces the rod-shaped molecule's rigidity and, consequently, its ability to fit readily into the parallel arrangement within the nematic phase. As a result, nematic phase stability decreases with increasing the alkoxy chain length. The end-to-end intermolecular interactions play a role in determining the SmC-toisotropic transition temperatures, that is, the construction of the smectic molecular order is determined by the fact that the terminal attractions become stronger, allowing the arrangement of the layers to occur more easily as the alkoxy chains increased, which in turn enhances the SmC-to-I transition.

When the present investigated coumarin azoesters are compared with coumarin esters for the corresponding alkoxy chain length, it is found that incorporation of phenyl azo group to the coumarin ester derivatives led to an increase in the polarizability of the whole compound and consequently enhanced the intermolecular association between molecules.

Normalized entropies of the smectic C-nematic $\left(\Delta S_{\mathrm{SmC}-\mathrm{N}} / \mathrm{R}\right)$ and nematic-isotropic $\left(\Delta S_{\mathrm{N}-\mathrm{I}} / \mathrm{R}\right)$ transitions for coumarinazoesters derivatives were calculated and appended to Table 1. Entropies of $\mathrm{N}-\mathrm{I}$ transitions $\left(\Delta S_{\mathrm{N}-\mathrm{I}} / \mathrm{R}\right)$ are of lower values than those of the corresponding $\Delta S_{\mathrm{SmC}-\mathrm{N}} / \mathrm{R}$ transitions. The decrease observed in $\Delta S_{\mathrm{N}-\mathrm{I}} / \mathrm{R}$ was presumably in part a reflection of the increase in the biaxiality of the mesogenic group, resulted from the flexible terminal alkoxy-chain, being less strongly anchored at its end, giving a resulting decrease in conformational entropy [32]. 

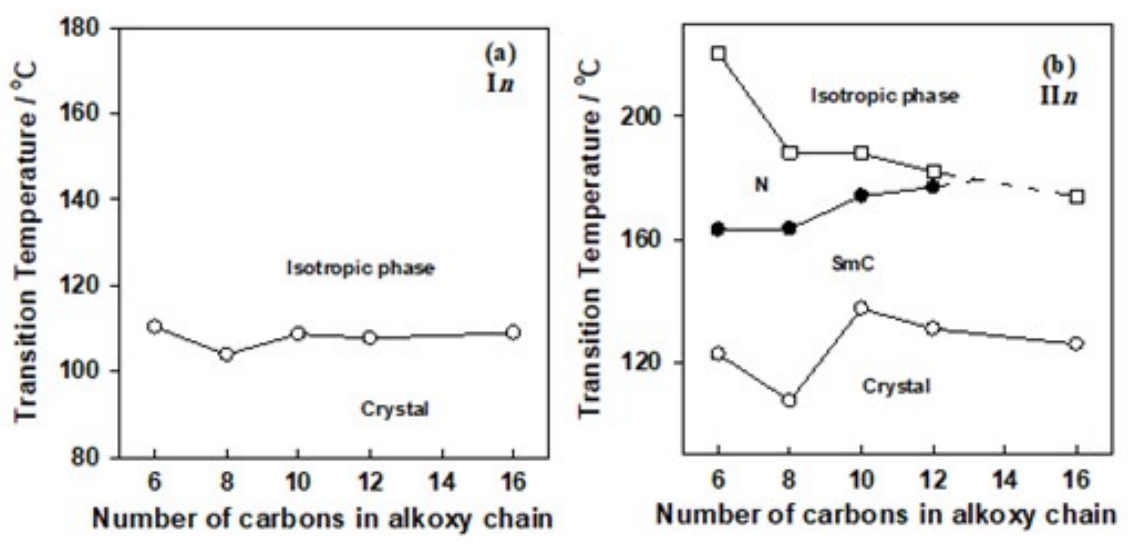

Figure 3. Effect of alkoxy-chain length on the mesophase behavior of the individual homologous series of (a) $\mathbf{I}_{n}$ and (b) $\mathbf{I I}_{n}$.

\subsection{Stabilities, Total Energies, Dipole Moments}

Since the mesophase stability of liquid crystalline compounds is dependent upon the intermolecular attractions, in which molecular polarity plays a significant role, it has been shown [33] that in a series of compounds the dipole moment of any compound is dependent upon the nature of the substituent. It has also been shown [34,35] that the dipole moments of all members of a homologous series are virtually the same irrespective of the alkoxy-chain length. The calculated total energies, dipole moments of the studied compounds are summarized in Table 2. The optimized structures of $\mathbf{I}_{6}$ and $\mathbf{I I}_{6}$ shown in Figure 4 were calculated using 6-311G(d,p) level of theory.

Table 2. Total energies (a.u), dipole moments (Debye) using B3LYP/6-31G(d,p) method.

\begin{tabular}{|c|c|c|c|c|}
\hline & \multicolumn{4}{|c|}{$I_{6}$} \\
\hline & $x$ & $\mathbf{Y}$ & $\mathbf{Z}$ & Total \\
\hline Dipole moment (Debye) & 3.98 & -1.62 & -1.47 & 4.44 \\
\hline \multirow[t]{3}{*}{ Energy (a.u.) } & \multicolumn{4}{|c|}{-1266.70} \\
\hline & \multicolumn{4}{|c|}{$\mathrm{II}_{6}$} \\
\hline & $X$ & $\mathbf{Y}$ & $\mathbf{Z}$ & Total \\
\hline Dipole moment (Debye) & -2.31 & 0.03 & -5.20 & 5.71 \\
\hline Energy (a.u.) & \multicolumn{4}{|c|}{-1607.11} \\
\hline
\end{tabular}
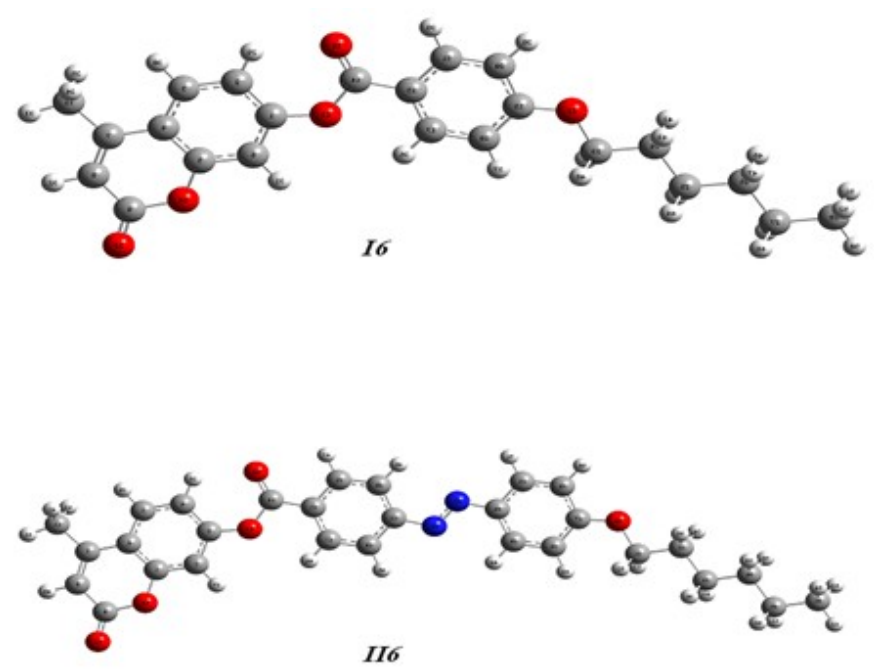

Figure 4. The optimized structures of $\mathbf{I}_{\mathbf{6}}$ and $\mathbf{I I}_{6}$. 
The results of energy analysis showed that $\mathbf{I}_{6}$ has energy -1266.70 a.u., while, $\mathbf{I I}_{6}$ has -1607.11 a.u. The high energy difference between the two compounds could be attributed to the extra conjugation of $\mathbf{I I}_{6}$ than the $\mathbf{I}_{6}$ due to the attachment of the extra azo phenyl group in the mesogenic part, while, the dipole moment of $\mathbf{I I}_{\mathbf{6}}$ is also more than that of $\mathbf{I}_{\mathbf{6}}$.

\subsection{Molecular Electrostatic Potential (MEP)}

The molecular electrostatic potentials of $\mathbf{I}_{6}$ and $\mathbf{I I}_{6}$ are given in Figure 5. Many properties such as molecular polarizability, dipole moment and electronic structure are highly affected by the charge calculations at atomic sites of compounds under investigations [36]. Moreover, the molecular electrostatic potential (MEP) is a useful property to study the distribution of the electron density [37-39]. In MEPs, the red color is the region of maximum negative charges. The studied compounds have more electron deficient centers which mainly localized on the esters group either of benzoate or coumarin moieties, while the electron rich region is located on the mehyl group of the coumarin part for both compounds. Also, the molecular electrostatic potential (MEP) is best suited for identifying the presence of intra- and intermolecular interactions on the different atomic sites.

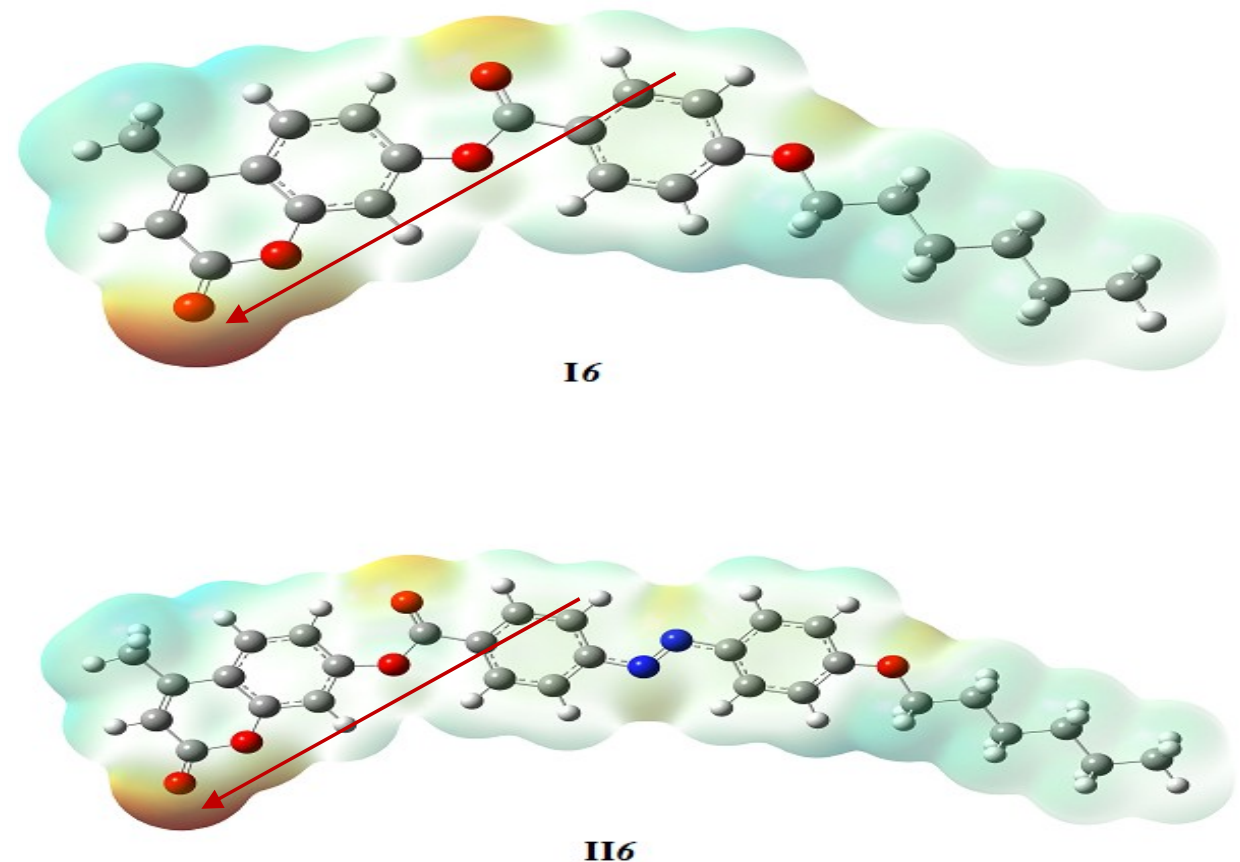

Figure 5. Molecular Electrostatic potentials (MEP) mapped on the electron density surface calculated by the DFT/B3LYP method.

\subsection{Frontier Molecular Orbitals}

One of the important properties for chemists and physicist is the nature of the frontier molecular orbitals (FMOs), like energy level and electron densities. The location of electron densities of FMOs are used for calculation of the reactive position in the compounds under investigation [40].

LUMO is the lowest unoccupied molecular orbital and HOMO is the highest occupied molecular orbital, and their energy gap $(\Delta \mathrm{E})$ shows the chemical reactivity of the molecule. The HOMO, LUMO and $\Delta E$ values of the studied compound were calculated by the B3LYP/6-311G(d,p) method. Where A molecule having high $\Delta \mathrm{E}$ is less polarizable and is generally associated with a low chemical reactivity and high kinetic stability [41]. The HOMO and LUMO pictures are shown in Figure 6. As shown in Figure 6 for compound $\mathbf{I}_{6}$, the electron densities of the HOMO and LUMO are mainly localized on the coumarin moiety, while that of $\mathbf{I I}_{6} \mathbf{H O M O}$ and LUMO is located on the azo part. Moreover, attachment of the azo group in $\mathbf{I I}_{6}$ affords HOMO and LUMO with lower energy difference (0.12311) rather than that of $\mathbf{I}_{6}(0.159128)$; it could be attributed to the extra conjugation of the azo part which decreases the 
energy difference between the frontier molecular orbitals. This lower energy difference $\mathrm{II}_{6} \mathrm{makes}$ it more polarizable than that of $\mathbf{I}_{6}$.

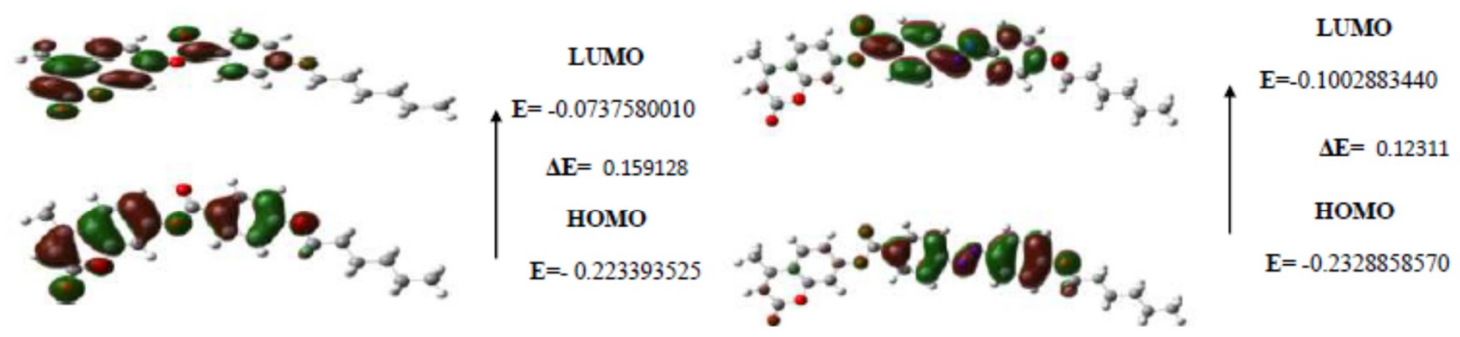

$I_{6}$

$\mathrm{II}_{6}$

Figure 6. The ground state isodensity surface plots for the frontier molecular orbitals.

\section{Conclusions}

Two groups of coumarin derivatives were synthesized and investigated for their mesophase behavior and stability. The study revealed that, irrespective of the length of the alkoxy chains, all compounds of the first group, 4-methyl-2-oxo-2H-chromen-7-yl 4-alkoxybenzoates, $\mathbf{I}_{n}$ were found to be non-mesomorphic, while 4-methyl-2-oxo-2H-chromen-7-yl 4-(2-(4-alkoxyphenyl)diazenyl) benzoates, $\mathbf{I I}_{n}$, were dimorphic possessing $\mathrm{SmC}$ and nematic phases, exceptthe compound $\mathbf{I I}_{16}(\mathrm{n}=16)$ is purely smectogenic has SmC phase. DFT calculations for coumarin derivatives were discussed and the result showed that the incorporation of azo group elongates the mesogenic core and hence decreases the energy differences between the FMOs and increases the dipole moments as well as the stabilities of coumarin azoesters series compared to coumarin esters.

Author Contributions: M.H. and H.A.A. designed of the experiment and carried out the laboratory work; M.H., H.A.A. and O.H. accomplished the data analysis and drafted the manuscript; All authors gave final approval for publication.

Funding: This article is supported by Deanship of Scientific Research, Taibah University (Research group No. 60334).

Conflicts of Interest: The authors declare no conflict of interest.

\section{References}

1. Zahradník, M. The Production and Application of Fluorescent Brightening Agents; John Wiley \& Sons: Hoboken, NJ, USA, 1982.

2. Zhou, S.; Jia, J.; Gao, J.; Han, L.; Li, Y.; Sheng, W. The one-pot synthesis and fluorimetric study of 3-(2'-benzothiazolyl) coumarins. Dyes Pigm. 2010, 86, 123-128. [CrossRef]

3. Mahadevan, K.M.; Harishkumar, H.N.; Masagalli, J.N.; Srinivasa, H.T. Synthesis and liquid crystal property of new fluoro coumarin carboxylates. Mol. Cryst. Liq. Cryst. 2013, 570, 20-35. [CrossRef]

4. Sun, Y.F.; Xu, S.H.; Wu, R.T.; Wang, Z.Y.; Zheng, Z.B.; Li, J.K.; Cui, Y.P. The synthesis, structure and photoluminescence of coumarin-based chromophores. Dyes Pigm. 2010, 87, 109-118. [CrossRef]

5. Pisani, L.; Muncipinto, G.; Miscioscia, T.F.; Nicolotti, O.; Leonetti, F.; Catto, M.; Caccia, C.; Salvati, P.; Soto-Otero, R.; Mendez-Alvarez, E.; et al. Discovery of a novel class of potent coumarin monoamine oxidase B inhibitors: development and biopharmacological profiling of 7-[(3-chlorobenzyl) oxy]-4-[(methylamino) methyl]-2 H-chromen-2-one methanesulfonate (NW-1772) as a highly potent, selective, reversible, and orally active monoamine oxidase B inhibitor. J. Med. Chem. 2009, 52, 6685-6706. [PubMed]

6. Cacic, M.; Trkovnik, M.; Cacic, F.; Has-Schon, E. synthesis and antimicrobial activity of some derivatives on the basis (7-hydroxy-2-oxo-2H-chromen-4-yl)-acetic acid hydrazide. Molecules 2006, 11, 134-147. [CrossRef] [PubMed]

7. Abdel-Wahab, B.F.; Mohamed, H.A.; Farhat, A.A. Ethyl coumarin-3-carboxylate: synthesis and chemical properties. Org. Commun. 2014, 7, 1. 
8. Buchs, J.; Gäbler, M.; Janietz, D.; Sawade, H. Coumarin-based emissive liquid crystals. Liq. Cryst. 2014, 41, 1605-1618. [CrossRef]

9. Tian, Y.; Akiyama, E.; Nagase, Y.; Kanazawa, A.; Tsutsumi, O.; Ikeda, T. Liquid crystalline coumarin polymers, 1 . Synthesis and properties of side-group liquid crystalline polymers with coumarin moieties. Macromol. Chem. Phys. 2000, 201, 1640-1652. [CrossRef]

10. Tian, Y.; Akiyama, E.; Nagase, Y.; Kanazawa, A.; Tsutsumi, O.; Ikeda, T. Synthesis and investigation of photophysical and photochemical properties of new side-group liquid crystalline polymers containing coumarin moieties. J. Mater. Chem. 2004, 14, 3524-3531. [CrossRef]

11. Kang, H.; Kang, D. Photoalignment behavior on polystyrene films containing coumarin moieties. Mol. Cryst. Liq. Cryst. 2015, 623, 45-55. [CrossRef]

12. Dröge, S.; O'Neill, M.; Löbbert, A.; Kitney, S.P.; Kelly, S.M.; Wei, P.; Dong, D. A new approach to photoalignment: photo-addition to a self-assembled monolayer. J. Mater. Chem. 2009, 19, 274-279. [CrossRef]

13. Obi, M.; Morino, S.y.; Ichimura, K. Factors affecting photoalignment of liquid crystals induced by polymethacrylates with coumarin side chains. Chem. Mater. 1999, 11, 656-664. [CrossRef]

14. Zhang, B.Y.; Meng, F.B.; Tian, M.; Xiao, W.Q. Side-chain liquid-crystalline polysiloxanes containing ionic mesogens and cholesterol ester groups. React. Funct. Polym. 2006, 66, 551-558. [CrossRef]

15. Singh, S.; Dunmur, D.A. Liquid crystals: Fundamentals; World Scientific Press: Singapore, 2002.

16. Weissflog, W.; Demus, D. Compounds with lateral long-chain substituents-a new molecule structure concept for thermotropic liquid crystals. Cryst. Res. Technol. 1983, 18, K21-K24. [CrossRef]

17. Weissflog, W.; Demus, D. Thermotropic liquid crystalline compounds with lateral long-chain substituents (II):: Synthesis and liquid crystalline properties of 1, 4-Bis [4-substituted-benzoyloxy]-2-n-alkylbenzenes. Cryst. Res. Technol. 1984, 19, 55-64. [CrossRef]

18. Weissflog, W.; Demus, D. New lateral long-chain substituted liquid crystals. Mol. Cryst. Liq. Cryst. 1985, 129, 235-243. [CrossRef]

19. Gray, G.W. Molecular Structure and the Properties of Liquid Crystals; Academic press: Cambridge, MA, USA, 1962.

20. Hagar, M.; Soliman, S.M.; Ibid, F.; El Sayed, H. Quinazolin-4-yl-sulfanylacetyl-hydrazone derivatives; Synthesis, molecular structure and electronic properties. J. Mol. Struct. 2013, 1049, 177-188. [CrossRef]

21. Soliman, S.M.; Hagar, M.; Ibid, F.; El Sayed, H. Experimental and theoretical spectroscopic studies, HOMO-LUMO, NBO analyses and thione-thiol tautomerism of a new hybrid of 1, 3, 4-oxadiazole-thione with quinazolin-4-one. Spectrochim. Acta A 2015, 145, 270-279. [CrossRef] [PubMed]

22. Hagar, M.; Soliman, S.M.; Ibid, F.; El Sayed, H. Synthesis, molecular structure and spectroscopic studies of some new quinazolin-4 (3H)-one derivatives; an account on the N-versus S-Alkylation. J. Mol. Struct. 1108, 667-679. [CrossRef]

23. Aboelnaga, A.; Hagar, M.; Soliman, S.M. Ultrasonic Synthesis, molecular structure and mechanistic study of 1, 3-Dipolar cycloaddition reaction of 1-Alkynylpyridinium-3-olate and acetylene derivatives. Molecules 2016, 21, 848. [CrossRef] [PubMed]

24. De Jeu, W.H.; Jeu, W.H. Physical Properties of Liquid Crystalline Materials; CRC Press: Boca Raton, FL, USA, 1980; Volume 1.

25. Jadzyn, J.; Czechowski, G.; Legrand, C.; Douali, R. Dielectric properties of 6-CHBT in isotropic and nematic phases. Liq. Cryst.: Chem. Phys. Appl. 2000, 4147, 184-190.

26. Gray, G. Liquid crystals and molecular structure-Nematics and cholesterics. Mol. Phys. Liq. Cryst. 1979, 1-29.

27. Melloni, A.; Rossi Paccani, R.; Donati, D.; Zanirato, V.; Sinicropi, A.; Parisi, M.L.; Martin, E.; Ryazantsev, M.; Ding, W.J.; Frutos, L.M.; et al. Modeling, preparation, and characterization of a dipole moment switch driven by Z/E photoisomerization. J. Am. Chem. Soc. 2010, 132, 9310-9319. [CrossRef] [PubMed]

28. Frisch, M.J.E.A.; Trucks, G.W.; Schlegel, H.B. Gaussian 09; revision a. 02; gaussian. Inc.; Carnegie Mellon University: Wallingford, CT, USA, 2009; p. 200.

29. Dennington, R.; Keith, T.; Millam, J. GaussView, version 5; Semichem Inc.: Shawnee Mission, KS, USA, 2009.

30. Dave, J.S.; Menon, M.R.; Patel, P.R. Synthesis and mesomorphic characterization of azoesters with a coumarin ring. Liq. Cryst. 2002, 29, 543-549. [CrossRef]

31. Imrie, C.; Taylor, L. The preparation and properties of low molar mass liquid crystals possessing lateral alkyl chains. Liq. Cryst. 1989, 6, 1-10. [CrossRef]

32. Imrie, C.T. Laterally substituted dimeric liquid crystals. Liq. Cryst. 1989, 6, 391-396. [CrossRef] 
33. Naoum, M.M.; Saad, G.R.; Nessim, R.I.; Abdel-Aziz, T.A.; Seliger, H. Effect of molecular structure on the phase behaviour of some liquid crystalline compounds and their binary mixtures II. 4-Hexadecyloxyphenyl arylates and aryl 4-hexadecyloxy benzoates. Liq. Cryst. 1997, 23, 789-795. [CrossRef]

34. Saad, G.R.; Nessim, R.I. Effect of molecular structure on the phase behaviour of some liquid crystalline compounds and their binary mixtures VI [1]. The effect of molecular length. Liq. Cryst. 1999, 26, 629-636. [CrossRef]

35. Minkin, V.I. Dipole Moments in Organic Chemistry; Springer Science \& Business Media: Berlin, Germany, 2012.

36. Sıdır, İ.; Sıdır, Y.G.; Kumalar, M.; Taşal, E. Ab initio Hartree-Fock and density functional theory investigations on the conformational stability, molecular structure and vibrational spectra of 7-acetoxy-6-(2, 3-dibromopropyl)-4, 8-dimethylcoumarin molecule. J. Mol. Struct. 2010, 964, 134-151. [CrossRef]

37. Scrocco, E.; Tomasi, J. Electronic molecular structure, reactivity and intermolecular forces: an euristic interpretation by means of electrostatic molecular potentials. Adv. Quantum Chem. 1978, 11, 115-193.

38. Politzer, P.; Murray, J.S. Relationships between dissociation energies and electrostatic potentials of $\mathrm{C}-\mathrm{NO}_{2}$ bonds: Applications to impact sensitivities. J. Mol. Struct. 1996, 376, 419-424. [CrossRef]

39. Marks, T.J.; Ratner, M.A. Design, synthesis, and properties of molecule-based assemblies with large second-order optical nonlinearities. Angew. Chem. Int. Ed. Engl. 1995, 34, 155-173. [CrossRef]

40. Fukui, K.; Yonezawa, T.; Nagata, C.; Shingu, H. Molecular orbital theory of orientation in aromatic, heteroaromatic, and other conjugated molecules. J. Chem. Phys. 1954, 22, 1433-1442. [CrossRef]

41. Sinha, L.; Prasad, O.; Narayan, V.; Shukla, S.R. FT-IR spectroscopic analysis and first-order hyperpolarisability of 3-benzoyl-5-chlorouracil by first principles. Mol. Simul. 2011, 37, 153-163. [CrossRef]

(C) 2018 by the authors. Licensee MDPI, Basel, Switzerland. This article is an open access article distributed under the terms and conditions of the Creative Commons Attribution (CC BY) license (http:/ / creativecommons.org/licenses/by/4.0/). 